\title{
Democratization and Its Implications for the Resolution of Ethnic Conflict in Myanmar
}

\author{
N. Ganesan
}

The process of democratization that began in 2010 in Myanmar has benefitted the peace process with the ethnic insurgent groups. While the first Thein Sein government was only nominally civilian and the democratization process itself is a top down effort initiated by the military, democratization has structurally and institutionally strengthened the peace process. The new NLD government that took office in April 2016 has now taken control of the process and has earned goodwill for its efforts in dealing with the ethnic minorities. Nonetheless, there is still sporadic fighting between the ethnic groups themselves as well as between some groups and the military, even as the government works towards a more comprehensive settlement.

Keywords democratization, Myanmar, ethnic conflict, NLD government, political transition

\section{Introduction}

Ethnic insurgency has very deep historical roots in Myanmar (also referred to as Burma) and is at least partly configured in terms of a majority-minority divide. There is also a geographical component in that many of the minority groups involved in ethnic insurgencies are highland peoples compared to the majority Bamar ethnic group that is predominantly a lowland people. Ethno-linguistic divisions in the country were reified during colonial times and also utilized by the post-independence elite for political purposes. Consequently, ethnic markers and conceptions of the virtuous self and the stereotypical other became well entrenched over time. The inability of the post-independence elite to overcome ethnic differences and insurgency is a reflection of the persistence of ethnicity as a major marker and source of division in the country's political template.

The earliest attempts to try and solve ethnic insurgency through negotiated peace settlements began after the collapse of the Burma Socialist Programme 
Party (BSPP) government in 1989. The military junta that succeeded the Ne Win government began signing a number of bilateral peace agreements to stem civil conflict from worsening the domestic political situation during a time of regime transition and widespread demands for democracy. Such agreements formed the preliminary framework for the nominally democratic Thein Sein government to cobble together a Nationwide Ceasefire Agreement (NCA) in October 2015. In other words, the process of peacebuilding began with the military government for the purpose of obtaining domestic tranquility during difficult times, and was then continued by a nominally civilian government whose leadership was drawn primarily from the military. However, only eight of the sixteen groups recognized by the government acceded to the NCA. Consequently, the first attempt at peacebuilding, despite being a long and drawn out process that involved both a military junta and a semi-civilian government, was not inclusive. The National League for Democracy (NLD) government that defeated the Thein Sein government in the November 2015 national election and assumed office in April 2016 has begun work on a new and much more inclusive peacebuilding mission. While its efforts are still in the early stages, a number of contours of the new approach are discernible. Ethnic grievances and tensions have existed since the country's political independence and the current government's efforts at securing lasting nationwide peace, while laudable, are by no means guaranteed.

The central argument of this article is that the process of democratization has overall benefitted the peace process in Myanmar. Yet, there are a number of nuances to both processes that should be kept in mind. The first of these is that the process of democratization began as a top down initiative of Senior General Than Shwe who stood down from power in 2010. Thein Sein, who was nominated by Than Shwe to succeed him as president and took power following an election in a nominally civilian government, continued the process and significantly liberalized it by engaging the political opposition. The NLD government led by Aung San Suu Kyi that came into power in 2016 and replaced the Then Sein government is much more democratic with civilian appointees. It has sought to further the peace process much more robustly, identifying it as the most important agenda item. While the new government has been much more conciliatory towards the ethnic minorities and won their trust, this is likely to be part of a long and drawn out process. Amidst such changes, important continuities linger as well. These include the important role of the military in supporting the democratic process as well as the leadership of the new government in the peace process. In this regard, the military continues to retain pride of place in domestic politics.

This article is divided into six major sections. The first section offers a broad working definition of democracy that is generally accepted as constitutive of a functioning democratic state. The second section traces the historical background to ethnic insurgency in Myanmar and places the discussion within 
a broader contextual perspective. The third section then goes on to identify the major efforts of previous governments, in particular the elected Thein Sein-led government, at peacebuilding, while the fourth section identifies the ongoing efforts of the NLD-led government to achieve peace. The fifth section identifies the opportunities and constraints that face the current government in its attempts to achieve peace, and the final section concludes the article.

\section{Democracy: A Working Definition}

Democracy refers to both a form of government or regime type as well as the existence of certain procedural norms in society on how political power is obtained and exercised. Additionally, there are a number of ways in which democracy can be practiced from a structural point of view. Philosophically, democracy is an expression of the principle that state sovereignty resides in the popular will as suggested by the French Enlightenment philosopher John Jacques Rousseau. Accordingly, those aspiring to public office should be publicly elected into office and exercise the associated powers for a specific term. The proviso of each adult eligible voter having a single vote also encapsulates the principle of equality.

Beyond such philosophical considerations, a number of structural attributes are deemed as prerequisites to a functioning democracy. Such features include the existence of political parties to aggregate voter interests and a system that does not discourage the formation of such parties. Political parties then become the avenue for those aspiring for political office. In fact, the American political scientist Robert Dahl concludes that inclusion and contestation are the cardinal features of a democratic government (Dahl 1971, 3). Here inclusion means the involvement of a wide segment of the population in the electoral process and contestation is a reference to the ability of political parties to compete against each other fairly. Dahl's minimalist definition is a reference to procedural protocols present in a functioning democracy. However, as a regime type, democracy is also associated with a number of soft features that include the freedoms of speech, movement, and association which are usually referred to as fundamental liberties. Such liberties in turn promote an active civil society that is regarded as important to a functioning democracy in order to articulate and aggregate interests. The existence of parapolitical organizations or individuals to perform a guardian or watchdog function over democratic norms is also not uncommon (Lawson 1993). Democratic theorists have more recently argued for the protection of minority rights as part of the democratic process-a proviso to prevent what is called the tyranny of the majority.

There are generally three models of democracy in practice today. The first, liberal democracy, privileges the individual and guarantees citizens' rights 
constitutionally over and above democratic practices. This form of democracy is widely practiced in North America and Western Europe. The second type tends to privilege communal well-being over that of the individual and is often referred to as welfare democracy. The Scandinavian countries and New Zealand have generally preferred such a form of democracy. Finally, the third variant, often referred to as consociational democracy, is practiced by countries where there is recognition of deep segmentation among the major communities and some attempt is made for the communities to be represented on a proportional basis. Belgium and Switzerland are generally regarded as the best examples of such practices (Lipjhart 1984). In democratic theory, it is also not uncommon to find arguments for the balance of classes and social groups so that political power is fairly dispersed and diffuse in order for the regime to endure (Kornhauser 1965, 136). American political scientists have however argued for the embeddedness of the middle class as a cardinal feature of democracies that in turn sustain the regime as well their interests in an interactive manner. Consequently, the literature sometimes reflects a tendency to privilege the middle class as an anchor of democracy.

\section{Historical Background of Ethnic Insurgency in Myanmar}

Myanmar, like many other countries in Southeast Asia, is home to a heterogeneous population. Like other countries in mainland Southeast Asia, the population is predominantly Tibeto-Burman or Sino-Thai in origin despite being broken down into many ethno-linguistic groups and sub-groups. The country was colonized by the British in three stages through armed conflict and was generally regarded as an extension of British territories in India with the administration of the country having been conducted from India until 1937 just prior to the outbreak of the Second World War. Additionally, such administration was piecemeal and was not grounded in the realities of Burma (Taylor 2007, 70-72).

The conclusion of the First Anglo Burmese War in 1826 led to the colonization of Arakan and Tennaserrim (current day Rakhine State and Tanintharyi Division) and opened up Burma's borders to migration from the Indian sub-continent. This migration was to have long term impact on Burma as Indians slowly trickled into the country and began to take up professional jobs as well as those available in the local civil service. Their fluency in the English language and familiarity with English laws and practices gave them a significant advantage over the locals. Additionally, the Chettiar money lenders also settled in the country and provided credit in exchange for collateral that often came in the form of farm land. These developments were to have a deleterious impact on the migrant Indian community later on as resentment would ferment over time and break out in anti-Indian race riots in the 1960s. Rakhine State in the west of 
the country also witnessed large scale migration that would pit the local Buddhist community against the migrants from Bengal and later on Bangladesh which would later result in strong anti-Muslim sentiments as well.

British colonization of the country was by no means complete notwithstanding the violent nature of the process. For the most part, they only managed to colonize the lowland areas that were subsequently referred to as Ministerial Burma. The highlands that were forested and prone to malaria were conveniently avoided. In order to pacify these minorities the British signed peace treaties with them and allowed them to administer their own territories through a system of indirect rule (Taylor 2007, 75). This differentiated administration sowed the seeds of division between different ethnic groups. The British preference for recruiting from highlanders for military service for their martial qualities also meant that the minorities were disproportionately represented in the Burmese army. All these developments eventually contributed to deep misunderstandings and mistrust between the Bamar majority and the ethnic minorities. The former regarded themselves as superior while the latter distrusted the motives of the former and sought to stave off their subservience.

The differences between the groups were brought to the fore just prior to political independence and the nationalist leader Aung San sought to assuage the fears of the minorities by advocating a federal structure that afforded autonomy to the frontier states. Consequently, when he formulated the Panglong Agreement in 1947 to unite upper and lower Burma, he offered full internal administrative autonomy to the Chin and Shan States and also offered political independence within a two year period should the federal arrangement fail. This liberal arrangement did not eventuate in the post-independence period as Bamar leaders sought political power and the minorities became disenchanted. The first group to lead a resistance against the central government was the Karen National Union (KNU) in 1949 and its troops almost captured Rangoon before military reinforcements arrived from Kachin State to deflect the threat. This pivotal development slowly led to the disintegration of the union as more and more ethnic groups set up private insurgent armies and eked out territories, often along the borders with neighboring countries like China, India, and Thailand. The domestic political situation also deteriorated in that Bamar politicians began to prefer Bamar supremacy and the Buddhist religion over others. As the situation deteriorated, the military staged its first coup in 1959 and appointed a caretaker government that lasted eighteen months. During the second coup in 1962, the military led by General Ne Win took over and dealt an end to parliamentary government. The new government embarked on a policy of radical socialism and created the BSPP to coordinate its policies. The presence of a large detachment of Chinese nationalist troops in the Shan State led to a covert proxy war between Chinese communists and the United States worsened the situation. Consequently, in addition to radical socialism, the BSPP government also adopted a foreign 
policy of neutrality through isolationism and cut itself off from the rest of the world (Ganesan 2005, 31-32). While the government was powerless to stop the U.S. Central Intelligence Agency from supporting the Chinese nationalist troops in their fight against the communist troops, it was hoped that this policy of passive neutrality would eventually minimize external interference in the country. The policy of isolationism and nationalization of the economy led in turn to a significant deterioration of the domestic economy and seriously stifled the country's development (Haacke 2006, 10; Steinberg 2001; Taylor 2009, 355 356).

\section{Peace Initiatives from 1988-2015}

The military junta that came into power after Ne Win stepped down in 1988 hurriedly began to cobble together ceasefire agreements with the larger ethnic armies. There were a number of reasons for this development. Firstly, Ne Win's resignation and decision to turn over power to younger leaders had created a political vacuum and uncertainty that needed to be dealt with. Secondly, this development coincided with the student-led demonstration for democracy that was violently suppressed by the military (Kyaw 2013). Thirdly, the Burmese Communist Party (BCP) that had fought the previous government collapsed and the Wa and Kokang ethnic groups that had been the sword of the BCP had to be contained. Finally, this tumultuous period in domestic politics coincided with Aung San Suu Kyi's return to care for her ailing mother. Her presence served to invigorate and unite a weak and splintered political opposition.

Arising from early efforts to contain the fallout from the collapse of the BCP, the military junta in power anointed General Khin Nyunt to begin bilateral ceasefire negotiations with many of the insurgent armies. Khin Nyunt served as both Prime Minister and head of the powerful Military Intelligence (MI) until his ouster by Senior General Than Shwe in October 2004. ${ }^{1}$ In this regard, it is important to note that, in the Myanmar case, the process of peace-building preceded the onset of democracy in 2010. Since leading members of the military continued to hold power as nominal civilian appointees in the subsequent government, the initiatives of both regime types is being dealt with collectively. This combined treatment allows for conceptual parsimony since the peace process is at the heart of this enquiry and how democratization has affected it in turn.

The terms of the early ceasefire agreements were rather liberal. Essentially the armed groups were allowed to operate within a clearly demarcated and contiguous piece of territory. They were also allowed to retain their weapons and the military had to serve notice when entering these ceasefire areas. A total of twenty ethnic armies signed such peace agreements (Smith 1999; Steinberg 
2006). The government's early success in concluding these agreements was reflected in its ability to persuade three of the most intransigent groups to sign similar deals in March 2012. These groups were the KNU, the Karenni National Progressive Party (KNPP), and the Chin National Front (CNF) (Ganesan 2014, 132). Simultaneously, the military mounted offensives against insurgent armies that refused to sign a ceasefire agreement. Additionally, the government began a National Convention as part of its seven point "roadmap to democracy" that was previously announced in 2003 (Holiday 2011, 82). However, the NLD, whose overwhelming political victory in the earlier 1990 election was not recognized by the government, and many of the ethnic groups refused to participate in the event as well. The military junta that was led by Than Shwe promoted the Convention as part of broader structural reforms to return the country to a democratic regime. Finally, the government was hoping to disarm the insurgent groups and have them participate in a Border Guard Force (BGF) that drew on soldiers from the military as well as insurgent armies. While some of the smaller groups acceded to this demand, the larger groups, like the Kachin, Karen, Shan, and Wa, rejected it outright (South 2008, 11).

The government's attempts to further consolidate the early peace agreements received a boost under the Thein Sein government that was elected to office in November 2010. The elections were held in part to secure much higher levels of domestic and international political legitimacy and also end the crippling wide ranging international sanctions regime that had been imposed by Western countries in 1993. While many of the office bearers of the new government were from the military, an earnest effort began on the part of the government to formalize the peace process and bring the ethnic insurgent groups into a broader nationwide peace process. In line with this thinking, Thein Sein issued a presidential decree and created two peace committees. The first of these was the Union Peace-making Central Committee that was housed in Parliament and headed by the President himself. The second committee was the Union Peacemaking Work Committee that was chaired by Vice President 1 Sai Mauk Kham. Additionally, Thein Sein established the Myanmar Peace Center (MPC) as the vehicle for coordinating the government's efforts and appointed U Aung Min as the lead ceasefire negotiator (Ganesan 2014, 131).

The government's intention was not only to centralize the peace process, but also to consolidate it at the national level. In line with this vision, it sought to consolidate the peace process at three levels. In the first, bilateral agreements would be signed at the regional level. Then these agreements would be consolidated at the state level, corresponding to the administrative division of the country into seven states and seven regions. And finally, it would convene a national meeting to ratify these agreements in Parliament at the national level. This much touted NCA was originally planned for April 2014. However, negotiations with many of the groups continued to drag on. There were a number 
of reasons for the delays in the process. Firstly, not all the groups trusted the government and the military after having been in conflict with both for so long. Secondly, the bilateral agreement with one of the largest groups, the Kachin Independence Organization/Army (KIO/KIA), collapsed in June 2011, and fighting between the government and this insurgent army was sustained and widespread. This development had a deleterious effect on the process in general, not least because the KIO also had influence on some of the other smaller groups through the United Nationalities Federal Council (UNFC) - an umbrella organization that brought together eleven ethnic groups. Finally, the Myanmar National Democratic Alliance Army (MNDAA - Kokang) launched a brazen attack on government forces in Laukkaing in March 2015. This attack led to a large number of fatalities and casualties for the government, and also negatively affected the process (Ganesan 2015, 278-279).

The MNDAA's attack infuriated the military that announced it would accept nothing short of a total surrender of the group before any negotiations could take place. Two other groups that were identified as having supported the MNDAA and also for refusing to sign ceasefire agreements were similarly dealt with. These two groups were the Arakan Army (AA) and the Tảang National Liberation Army (TNLA) of the Palaung ethnic group. The military refused to include these three groups in any ceasefire negotiations. Additionally, it also refused to include three smaller groups on the grounds that they were political organizations that did not have an army. These are the Wa National Organization, Lahu Democratic Union, and Arakan National Council (ibid., 279). Consequently, notwithstanding the position of the ceasefire negotiators, the military remained adamant in excluding these six groups from any peace deals. In fact, the military had not always been in agreement with negotiators from the MPC who were sometimes viewed as being too generous and for ignoring the realities on the ground, in particular military casualties and operational considerations. And at the executive level, there was also unhappiness with peace negotiators since Parliament was not regularly briefed on the process. As a result, there was sometimes a three way tug of war that was waged just on the government side. The ethnic armies were also not very coordinated in their approach, with a large number of organizations claiming to represent their corporate interests (ibid., 279-280).

Finally, only eight of the sixteen groups that had been identified by the government for inclusion in the formal peace process acceded to the NCA that was eventually signed amidst much fanfare in October 2015 just before the Thein Sein government's term expired. Following this signing, the government and the ethnic groups set up a Nationwide Ceasefire Agreement Joint Implementation Coordination Meeting. Out of this meeting evolved a Joint Ceasefire Monitoring Committee whose task is to liaise with the signatories and the government on negotiating and implementing the relevant protocols that have been agreed upon.

While the Thein Sein government had formalized the peace making process 
and signed the NCA in 2015, a number of observations are noteworthy. The first of these is that the process leveraged on the earlier bilateral peace agreements that has already been signed between the previous military government and the ethnic insurgent groups. However, the NCA only succeeded in bringing eight out of the sixteen groups that the government had hoped to bring into the fold. Consequently, the agreement is not an inclusive one. The largest group that acceded to the NCA is the KNU while the largest abstention was the KIO. Then there were groups like the United Wa State Army (UWSA) that refused to be a part of the process, arguing that the previous bilateral agreement was working well and that there was no need for it to be replaced by another agreement. The non-signatories are also insisting that all groups be involved in the negotiations and agreement, including the MNDAA, AA, and TNLA. The military has refused this request thus far. In fact, government ceasefire negotiators also argued the existence of a "northern faction" among the insurgent groups-a reference to the Wa, Kokang, Shan and Kachin groups-that appears to be influenced or supported by China. ${ }^{2}$ If this observation is indeed true, then China, which has taken an interest in and sent monitors to the negotiations, will have to be persuaded to support the efforts of the government. Importantly, this revelation also means that lead negotiators from Myanmar and the military are not always convinced that China is an innocent and neutral party to the peace process. And finally, no agreement can be reached without the explicit agreement of the Myanmar military regardless of what government negotiators hope to achieve. The military, which controls the Ministries of Defense, Border Affairs, and the Interior, will have to be involved and offer support if any agreement is to be formalized and implemented.

\section{The NLD-led Government's Approach to Peacebuilding}

It has been approximately a year since the NLD took over the reins of government in April 2016. Consequently, its approach to the peace process is still evolving, although a number of major strands of the new policy are clearly discernible. The first of these strands is that the new government no longer pursues peace negotiations through the MPC that was commissioned by the previous government in Yangon. Instead, it has set up its own coordinating body in Naypyitaw called the National Reconciliation and Peace Centre (NRPC) (Eleven Newsmedia Myanmar 2016b). Additionally, Suu Kyi has appointed her personal physician and confidant Dr. Tin Myo Win as the government's interlocutor with the ethnic groups. He met with the UNFC's Delegation for Political Negotiation (DPN) in Chiangmai in early June 2016 and then positioned himself to deal with the UNFC after the group's Maijayan Summit in late July (Eleven Newsmedia Myanmar 2016a). In policy terms, Suu Kyi has clearly signaled that 
the achievement of peace with the ethnic groups is foremost on her agenda going forward.

In line with a broadly publicized campaign to elevate and protect the interests of the ethnic minorities, Suu Kyi has undertaken a number of high profile initiatives. These include the setting up of a Ministry of Ethnic Affairs despite pruning the number of Ministries from thirty-three to twenty-three. Additionally, she has appointed Naing Thet Lwin, an ethnic Mon, to the position. She has also been conciliatory towards the ethnic groups by nominating minority candidates for executive appointments in the new government. Ti Khun Myat, Deputy Speaker of Parliament, is Kachin and from the military's Union Solidarity and Development Party (USDP). The Upper House Speaker, Mahn Win Khaing Than, is ethnic Karen and his Deputy Aye Thar Aung is a Rakhine Buddhist from the Arakan National Party (ANP) (Ganesan 2017). These initiatives are meant to signal the incumbent government's political will to involve the ethnic minorities in the exercise of executive political power and deflect criticisms that it is a proBamar institution like previous governments. If this strategy succeeds, it will allow the government to deal with the situation from a structural rather than an ethnic point of view, making agreements far easier to obtain. This strategy is however likely to be a long and drawn out process.

Notwithstanding fissures from the approach pursued by the previous government, Suu Kyi has also gone on to accommodate the progress made under the previous regime. In this regard she is supportive of the NCA and the Joint Monitoring Commission and is seeking ways to bring both the signatories and non-signatories to the NCA together as part of a larger national process. Additionally, she appointed U Hla Maung Shwe, who previously served as a senior adviser to the MPC, as the Secretary of the Preparation Committee for Holding the Union Peace Conference. This Committee was tasked with arranging what was being touted as the Twenty-first Century Panglong Conferencesignaling a link between the meeting with the ethnic groups in late August 2016 and the Panglong Conference arranged by her father Aung San in 1947. This catchy title and linkage was used by both the government and the ethnic groups as part of the agenda setting process. The new government intends to signal that the Conference will emulate the liberal federalist sentiments that typified Aung San's approach in his dealings with the ethnic minorities. For the ethnic groups, the name serves to remind all of the promise of internal autonomy in administration for the ethnic states although it is unlikely to signal the possibility of secession like the previous document. In fact, all the groups have indicated that they will not secede from the Union, a position that is regarded as non-negotiable by the military.

Other discernible features of the new government's approach is for the peace negotiation and related processes to be as inclusive as possible. In this regard, it invited representatives from political parties, ethnic groups, and civil 
society organizations to be part of the process as well. Between three to five persons from organizations representing these groups were invited. While this development is important in making the process widely consultative and visible, the increased number of people and groups puts pressure on the process itself and makes coming to an agreement more difficult. Only the signatories, however, have bargaining power in the process, and the rest were merely observers to an important national process. As part of the process of engagement, Suu Kyi also met with the UNFC that coordinates policies for eleven ethnic groups (Bangkok Post 2016). The UNFC, which called for a summit meeting of all the ethnic groups in Maijayan in Kachin state in late July, hoped to present a unified position on behalf of the ethnic groups and especially the non-signatories to the NCA. And the government had in turn offered to facilitate transportation for ethnic groups to attend the summit as a goodwill gesture.

Suu Kyi is clearly well placed structurally to engage the ethnic groups. After parliamentary ratification, she is now State Counsellor and therefore wields independent political and administrative power. Hence she has the capacity to articulate government policies on the peace process. And although she is barred from the presidency for having children with foreign nationality under the terms of the 2008 Constitution, President Htin Kyaw is also her confidant and appointee. Additionally, as Minister for Foreign Affairs she also sits on the powerful National Security Council and is able to negotiate with neighboring countries like China and Thailand whose goodwill and cooperation is essential to secure lasting peace. Additionally, she involved the United Nations (UN) by inviting Secretary-General Ban Ki Moon to witness the signing of the TwentyFirst Century Panglong Agreement in August. This agreement has given the peace process an added boost and the inclusion of prominent international personalities also gives the agreement more credibility both domestically and internationally. Added on to the strong political legitimacy that she currently enjoys, such developments strengthen the overall process and pressures all parties to seek an acceptable agreement.

\section{Existing Opportunities and Constraints to Peacebuilding}

The Myanmar situation at once presents both opportunities and constraints to the newly elected government's peace making initiatives with the ethnic groups. Arguably many of the opportunities are associated with the new democratically elected regime and the positive signals that it has sent towards the ethnic groups thus far. Conversely, it is arguable that there are constraints as well, and many of these are tied to political and structural conditions that have crystallized over time.

To begin with the opportunities, the leadership of Suu Kyi and the NLD 
government is the most important development that has affected the tone and tenor of the government's relationship with the ethnic groups. The new government has made it very clear that the peace process is its foremost priority in governance. It has also clearly signaled that it is likely to be much more accommodative than the previous government and is veering in favor of federal arrangements that are likely to provide states with more autonomy. Suu Kyi's standing in the government, the appointment of Dr. Tin Myo Win, and the creation of a new structure in Naypyitaw to deal with the process are all clear signals to the ethnic groups that she has both the political will and the authority to push the process forward. Her meeting with the UNFC and the call to make arrangements for a new Twenty-first Century Panglong Conference by August also indicated the urgency of the task. All of these developments have led to the ethnic groups being much more positive in their dealings with the government and hopeful that difficult and outstanding issues can be solved. The creation of a new Ministry of Ethnic Affairs and her appointments of ethnic minority candidates to senior executive positions in the new government are all indicative of a much more accommodative approach. Such initiatives have won her much goodwill and trust with the ethnic minorities that in the past always distrusted the government and accused it of discrimination against them. Additionally, in perceptional terms, the ethnic groups widely regard the NLD government as a much more legitimate negotiating partner than the previous government and the military given the former's strong electoral victory and public standing.

The new government's urgency in resolving the issue of ethnic insurgencies notwithstanding, there are a number of other factors that must be considered, and this leads to a sober understanding of the situation at hand. These considerations are mostly structural in nature and pertain to both the ethnic groups as well as the structure and responsibilities of the current government. The first consideration is that the ethnic groups themselves are by no means united on issues. There are a plethora of organizations claiming to represent their interests and some of these have overlapping memberships. The UNFC itself comprises only eleven of the twenty-one groups that have identified themselves as interlocutors with the government. Out of these twenty-one, the military is not keen to deal with six of the organizations as stated previously. Of these six, three are regarded as political parties and the other three have engaged government troops on numerous occasions with casualties on both sides. Consequently, the military is likely to be unwilling to deal with these six groups and has indicated that the three with which it has fought recently will be required to surrender first as a precondition to talks. This position will certainly be held firm against the MNDAA which initiated the assault on Laukkaing in March 2015. Despite the military's position, the UNFC has asserted that the peace process must be an inclusive one that involves all the ethnic insurgent groups. It is difficult to see how this difference in opinion will be reconciled to the mutual satisfaction of all parties involved. 
The Kachin KIO/KIA has the strongest representation in the UNFC and it has also demanded that the government accept the resolutions adopted at the Maijayan Summit held at the end of July. Again, it is unlikely that both the government and the military will completely accept the unilateral resolutions of the UNFC. There are also disagreements among the groups as well that have deteriorated into armed conflict. For example, since the signing of the NCA, there have been widespread clashes in the Shan states between the Restoration Council of the Shan States (RCSS), which is a signatory to the NCA, and the TNLA, which does not even have a bilateral ceasefire agreement with the government. More recently, there have been clashes between the Democratic Karen Buddhist Army (DKBA) and the Border Guard Forces (BGF) and the military in the Tanintharyi Division. This fighting alone displaced some 5,000 villagers fleeing the fighting and some crossed the border into Thailand in September 2016 (Irrawaddy 2016). Both governments are now making plans for returning the refugees. And among the largest groups, the KNU is the most supportive of the NCA while the KIO/ KIA is the most skeptical. The KIA has regularly fought with the military since the collapse of its ceasefire agreement in June 2011. And finally, the group with the largest standing army, UWSA, is not keen on signing any more agreements with the government. In fact, its representatives stormed out of the Twenty-first Century Panglong Conference and took offense to the fact that proper protocol was not observed for its inclusion as a participant. ${ }^{3}$

There are at least two other major complications from the ethnic side. The first of these is the fact that all the groups expect that they will be allowed to retain their private armies and weapons as a guarantee just in case any agreement fails. While this may be agreeable as an interim measure, the process of disarmament is likely to be part of the agenda at some point going forward. However, thus far none of the groups have indicated interest in laying down their weapons. Then there is the question of the involvement of China that is viewed as affecting the decisions of the "northern faction." These groups have close links with China and groups like the Wa and the Kokang are ethnic Chinese and actually use Mandarin in their administrative areas as well as the Chinese yuan rather than the Myanmar kyat for economic activities. Since many of these insurgencies have been in place for more than fifty years, there is also the question of the affected regions' political economy. Many of these groups maintained their financial independence through controlling forests for hardwood timber and gem rich mining areas. In fact, over the last few years, the most serious bouts of fighting between the KIA and the military have occurred when the military seized illegally felled timber and equipment used to fell and transport it. Hence there is also the question of access to natural resources and how these will be fairly divided.

Then there are structural complications that arise on the government side of the equation, and much of this has to do with the pride of place of the country's military within the framework of the 2008 Constitution. The first and perhaps 
most important of such provisos is the military's control of the Ministries of the Interior, Defense, and Border Affairs. The last two of these will clearly be involved in peace negotiations. The military is operationally deployed in many of the areas where the insurgent groups are based, especially in areas where it has been fighting some of these groups. Additionally, many of the ethnic armies are located in the areas that border China, India, and Thailand, and these areas come under the jurisdiction of the military as well.

The military is automatically entitled to 25 percent of all the seats in the state and federal parliaments and also maintains a majority of six nominees in the National Security Council that will be entrusted with decision-making affecting ethnic groups and conflict areas. And finally, the Constitution empowers the military to override the country's president and intervene in the domestic political situation to ensure sovereignty and compliance with the Constitution (Taylor 2009, 498). In light of all these constitutional provisions, it is clear that the military is not only a party to the peace process, but that the military has to agree for any peace process to succeed. Consequently, the military is a third party to the negotiations in addition to the government and the ethnic groups. While Suu Kyi's relationship with the military has been cordial thus far, it may be remembered that military appointees in Parliament voted against the creation of the position of State Counsellor for her and even stood up in unison to indicate their displeasure. This fluid dynamic of the relationship between Suu Kyi and the military is articulated at the highest echelons of the military and the present signals are all positive. The fluidity of the situation was highlighted when Thein Sein, who became an ally of Suu Kyi as part of the democratization process, fell out of favor by 2014 when the USDP moved against House Speaker Thura Shwe Mann who was viewed as being too close to Suu Kyi and threatening the vested interests of the military within the evolving parliamentary system (Reuters 2015).

A secondary question that emerges from the process of democratization is whether there has been a transformation in the process of violence and a movement of it away from ethnicity to religion. After all, even as successive governments after 2010 have sought to quell ethnically inspired violence, there has been a massive upsurge of religiously defined violence targeting Muslims. It began in 2012 and persisted until 2014 after the worst outbreaks of it were contained in Rakhine State in June and October 2012 and Meiktila in the Mandalay Division in 2014. There have also been sporadic outbreaks of similar violence in Oakkan on the outskirts of Yangon and Lashio in the northern Shan States. As a result of all this violence and the slow response of the security forces, there are now approximately 150,000 internally displaced persons in Rakhine State who are mostly Muslims that bore the brunt of the violence. This issue has attracted much international condemnation and even tarnished the reputation of the current government for being unable to deal with the issue satisfactorily.

While it may be difficult to attribute the causality of this new religious 
violence to the process of democratization and the ensuing transformation of the conflict, the new government has also identified it as an important agenda item for resolution. Against much domestic criticism, especially those emanating from Rakhine State, Suu Kyi established an Advisory Council on Rakhine State that is led by former-UN Secretary-General Kofi Annan (Myanmar Times 2016b). Additionally, to thwart the Buddhist monkhood from mobilizing negative public opinion against the Muslim community in the country, she has deftly dealt the leading Buddhist group Mabatha a body blow. This group, which sought to incite hatred against Muslims and advocated a boycott of Muslim owned businesses in the country, was denounced and disowned by the State Sangha Maha Nayaka Committee that oversees Buddhism in the country (Myanmar Times 2016a). Additionally, the Rakhine police bluntly warned that monasteries holding political discussions will be subjected to legal action (Eleven Newsmedia Myanmar 2016c). And most importantly, the NLD government nominated Rakhine State's Chief Minister against the wishes of the majority ANP that has a history of anti-Muslim rhetoric. The 2008 Constitution privileges the government in the appointment of state Chief Ministers regardless of the outcome of state elections. In light of all these developments, it may be argued that the new government has been proactive in dealing with religious violence since it took office.

\section{Conclusion: Democratization and the Peace Process in Myanmar}

When appraising peace related developments since the onset of the democratic process in Myanmar from 2010, it is clear that democratization has indeed been beneficial to the peace process. While the military junta that was in power before 2010 managed to sign a number of important bilateral peace agreements, these were aimed at stabilizing the domestic political situation given the confluence of simultaneous challenges that arose after 1988. These initiatives were then formalized by the nominally civilian Thein Sein government. It was able to articulate a more coherent program that worked towards securing ceasefire agreements and sought to broaden an existing process to include as many groups as possible. The government also benefitted from the fact that most of the holders of executive power were previously from the military and could therefore work more closely with the military. It was a fairly well-known fact that President Thein Sein had a good relationship with General Min Aung Hlaing, the army commander. Hence, there was a convergence of interests between them, albeit the military was not always enthusiastic about the power granted to the peace negotiators. Whether the military will be able to achieve similar rapport with the NLD government remains to be seen. The NLD government must however surely know that an agreement that does not have the support of the military has no chance of succeeding. Conversely, the military is also aware that the ethnic groups 
have much more faith in the new civilian government and are therefore more willing to negotiate and resolve their differences to mutual satisfaction. Therefore, cross-cutting and overlapping interests favor the evolution of a better relationship between the current government and the military.

There are other important personal relationships that were key to the unfolding of the democratic process in the country. The August 2011 meeting between Thein Sein and Suu Kyi that subsequently led to the registration of the NLD to compete in the April 2012 by-elections was an important development (Kyaw 2012). Likewise, the meetings between Than Shwe and Min Aung Hlaing on the one hand and Suu Kyi on the other, and their support for the democratic process and the pledge to uphold the outcome of the 2015 elections, were also important events that served to entrench the democratic process (Eleven Newsmedia Myanmar 2015). All these meetings and the personalities involved were crucial to the evolution of democracy, albeit many of the initiatives were top down and the involvement of leading members of the military seemingly signifies that this is a gradual devolution of power. In this regard, there are some remarkable continuities in the evolution of both democratization as well as its correlation with the peace process in turn. Externally, the lifting of the sanctions regime, which was previously imposed on the government, in 2011 also aided the democratization process. The international goodwill and assistance pledged to the democratic transition and the peace process by the European Union, Japan, United States, and the UN were other important external catalysts.

The newer NLD government is certainly more democratic in that the executive and Parliamentarians comprise civilians who were elected into office. Nonetheless, many of the new Parliamentarians are young, with an average age of thirty-five, and have little experience in formal politics. There is much goodwill at the national level and Suu Kyi continues to be immensely popular at the ground level and also has very high levels of grassroots and structural political legitimacy. Both the ethnic groups and the military are familiar with this political reality at the ground level. Suu Kyi has also taken ownership of the peace process with her own appointees and organization to steer the process. Additionally, she has sent positive signals to the ethnic groups and clearly indicated that the peace process is her most immediate and important agenda item. Importantly, she has also broadened the process to include political parties and civic groups to make the process much more inclusive. Such an approach is also well within democratic norms of governance. In this regard, the ethnic groups are likely to treat her seriously and work hard at achieving an acceptable deal. This convergence of interests for all the parties concerned and the collective feeling that the time is now appropriate to seal a workable, long-term ceasefire deal provides another catalyst to the process. How well the situation unfolds depends in turn on whether all parties are prepared to compromise their positions for the benefit of longterm peace and security. And for such a situation to materialize, international 
organizations and neighboring countries are likely to have an important role to play as well. From a geostrategic point of view, China is the most important external actor in its ability to influence the "northern faction" while Thailand and India are also likely to figure in the containment of cross border incursions.

\section{Acknowledgements}

An earlier version of this article was delivered at the workshop entitled "Postconflict Peacebuilding and Democratization in Asia: The Role of Democracy," at Seoul National University, August 25-26, 2016. The author would like to thank the discussants and workshop participants for their comments and suggestions.

\section{Notes}

1. The military government had signed bilateral ceasefire agreements with some twenty ethnic insurgent groups by 2004. These were the Kachin Independence Organization (KIO), New Democratic Army (Kachin), Palaung State Liberation Organization, Myanmar National Democratic Alliance (MNDA - Kokang), Kachin Defense Army, Myanmar National Solidarity Party (Wa), National Democracy Alliance Army - Military Local Administration Committee (Shan/Akhar), Shan State Army (SSA), Pa-O National Organization, Shan State Nationalities People's organization, Mong Tai Army (MTA), Kayan National Guard, Kayinni National Progressive Party (KNPP), Kayan New Land Party, Kayinni National People's Liberation Front and New Mon State Party (NMSP). The agreement with the KIO broke down in June 2011.

2. This observation was made on a number of occasions by ceasefire negotiators in late 2013 and early 2014. Leading members of the government, senior bureaucrats, and the military all spoke of the existence of this faction.

3. An ex-ceasefire negotiator told me during an interview on September 9, 2016 in Yangon that, unlike in the past, the Ministry of Foreign Affairs made the arrangements for the talks utilizing the normal protocol that privileged incumbent executives, and this in turn caused some problems. He also mentioned that whereas physical assets of the MPC had been transferred to the new government, much of the good will that had been built with the ethnic armies over the years could not be transferred on account of new appointees to the process and that such good will was therefore dissipated.

\section{References}

Bangkok Post. 2016. "Myanmar's Suu Kyi holds landmark rebel talks." July 17. http://www. bangkokpost.com/print/1037929/ (accessed March 22, 2017).

Dahl, Robert A. 1971. Polyarchy: Participation and Opposition. New Haven: Yale University Press. 
Eleven Newsmedia Myanmar. 2015. "Than Shwe meeting a major achievement: Suu Kyi." December 11. http://www.elevenmyanmar.com/politics/shwe-meeting-majorachievement-suu-kyi (accessed March 22, 2017).

Eleven Newsmedia Myanmar. 2016a. "Government to meet Wa, Mongla armed groups." June 7. http://www.elevenmyanmar.com/politics/government-meet-wa-monglaarmed-groups (accessed March 22, 2017).

Eleven Newsmedia Myanmar. 2016b. "Aung San Suu Kyi to lead NRPC.” July 6. http://www. elevenmyanmar.com/politics/5342 (accessed March 22, 2017).

Eleven Newsmedia Myanmar. 2016c. "Political discussions restricted in monasteries, Rakhine police chief.” August 29. http://www.elevenmyanmar.com/local/5794 (accessed March 22, 2017).

Ganesan, N. 2005. "Myanmar's Foreign Relations: Reaching out to the World." In Myanmar: Beyond Politics to Societal Imperatives, eds. Kyaw Yin Hlaing, Robert H. Taylor, and Tin Maung Maung Than, 30-55. Singapore: Institute of Southeast Asian Studies.

Ganesan, N. 2014. "The Myanmar Peace Center: Its Origins, Activities and Aspirations." Asian Journal of Peacebuilding 2 (1): 127-141.

Ganesan, N. 2015. "Ethnic Insurgency and the Nationwide Ceasefire Agreement in Myanmar." Asian Journal of Peacebuilding 3 (2): 273-286.

Ganesan, N. 2017. “Appraising Myanmar's Democratic Transition and Evolving Challenges." Japanese Journal of Political Science 18 (1): 196-215.

Haacke, Jurgen. 2006. Myanmar's Foreign Policy: Domestic Influences and International Implications. London: Routledge.

Holiday, Ian. 2011. Burma Redux: Global Justice and the Quest for Political Reform in Myanmar. Hong Kong: Hong Kong University Press.

Irrawaddy. 2016. "DKBA Splinter Group Lose Several Bases to Burma Army and Border Guard Force." September 16. https://www.irrawaddy.com/news/dkba-splinter-grouplose-several-bases-to-burma-army-and-border-guard-force.html (accessed March 22, 2017).

Kornhauser, William. 1965. Politics of Mass Society. London: Routledge and Kegan Paul.

Kyaw, Yin Hlaing. 2012. “The Unexpected Arrival of a New Political Era in Myanmar." Unpublished paper.

Kyaw, Yin Hlaing. 2013. “The Four Eights Democratic Movement and Political Repression in Myanmar." In State Violence in East Asia, eds. N. Ganesan and Sung Chull Kim, 231-256. Lexington: University Press of Kentucky.

Lawson, Stephanie. 1993. "Conceptual Issues in the Comparative Study of Regime Change and Democratization." Comparative Politics 25 (3): 183-205.

Lipjhart, Arendt. 1984. Democracy: Patterns of Majoritarian and Consensus Government in Twenty-one Countries. New Haven: Yale University Press.

Myanmar Times. 2016a. "State Sangha Disowns Committee for the Protection of Nationality and Religion." July 13. http://www.mmtimes.com/index.php/nationalnews/21344-state-sangha-disowns-committee-for-the-protection-of-nationality-andreligion.html (accessed March 22, 2017).

Myanmar Times. 2016b. "Anger over international experts appointed to Rakhine Commission." August 29. https://www.google.co.kr/search?q=Anger+over+internatio nal+experts+appointed+to+Rakhine+Commission\&oq=Anger+over+international+ experts+appointed+to+Rakhine+Commission\&aqs=chrome..69i57.575j0j4\&sourceid 
$=$ chrome\&ie $=$ UTF-8 (accessed March 22, 2017).

Reuters. 2015. "Myanmar party chief ousted over ties to rivals, contentious bills." August 15. http://www.reuters.com/article/us-myanmar-politics-idUSKCN0QK0DV20150815 (accessed March 22, 2016).

Smith, Martin. 1999. Ethnicity and the Politics of Insurgency. London: Zed Books.

South, Ashley. 2008. Civil Society in Burma: The Development of Democracy amidst Conflict. Honolulu: East -West Center.

Steinberg, David I. 2001. Burma: The State of Myanmar. Georgetown: Georgetown University Press.

Steinberg, David I. 2006. Turmoil in Burma: Contested Legitimacies. New York: Eastbridge. Taylor, Robert H. 2007. "British Policy towards Myanmar and the Creation of the 'Burma problem.” In Myanmar: State, Society and Ethnicity, eds. N. Ganesan and Kyaw Yin Hlaing. Singapore: Institute of Southeast Asian Studies.

Taylor, Robert H. 2009. The State in Myanmar. Singapore: NUS Press.

N. Ganesan is Professor of Southeast Asian Politics at the Hiroshima Peace Institute in Japan where he has been since 2004. From 2011 to 2013 he held a concurrent invited Visiting Professorship at the National Graduate Institute for Policy Studies (GRIPS) in Tokyo. His research interests are in sources of interstate and intrastate tensions in Southeast Asia and his most recent major edited works include Conjunctures and Continuities in Southeast Asian Politics and Bilateral Legacies in East and Southeast Asia. Since 2013 he has served as coordinator and trainer for the Myanmar civil service and faculty at Dagon and Mandalay Universities with German funding. 
